\title{
Things Not Easily Believed: Introducing the Early Modern Relation
}

\author{
THOMAS V. COHEN \\ York University \\ GERMAINE WARKENTIN \\ University of Toronto
}

\begin{abstract}
"On 14 April, 2009, there took place at Victoria College in the University of Toronto a scholarly workshop dedicated to the subject of the relazione or relation as a literary genre in early modern Europe. Among the several papers presented..."
\end{abstract}

$\mathrm{W}$

ere we to begin this introductory essay in the manner of an early modern relation, we would start not by stating facts about the things that happened, as above, but by speaking directly to our readers. First there would be the obligatory captatio benevolentiae, about our humble pens and faltering minds, and then in a bid for credit we would remind you that despite all this humility we, the editors, are seasoned scholars who indeed heard the discussions in question. We would parade titles and academic positions, lending the prestige of office to our own narrative. Only then would we launch into a description in which our own observant eyes and ears witnessed to the reader that what we were describing really occurred.

In that spirit, let us relate how this collection came about. One of us reviewed Filippo de Vivo's fine Information and Communication in Venice (Oxford University Press, 2007). The other, reading the review, was caught by a passage towards the end. We quote it here, as it sets out what became the subject for the papers in this collection.

Let me end with one example of close reading's pleasant fruits: De Vivo's subject, as in his title, is information. This term is ours; it suggests modern theories about noise, bandwidth, and storage capacity. It abstracts, 
as if data were some supplement to matter and energy, a quantifiable semisubstance shaping our political economy. But what did Renaissance Venetians call this stuff? Did they even have a name for it? Not quite, or so we learn from the old sources in De Vivo's bibliography. There, title after title, we descry not the data but the telling: almost always titles name not the thing described but the very act and effort of description: there trumpet relationi, discorsi, lettere, avvisi, avveritimenti, ragguagli (reports) and one document "ove chiaramente si scuopre" (where one lays out clearly) the subject. Indeed there is also one informatione, but, like all the others, the term there refers to the writer's striving. In all these titles, the writer, or title's author, calls attention not to the told but to the act of telling. The author, naming his report, conjures up his own voice and his audience. As would De Vivo himself, we note once more the intimate ties, then still strong, between writing and its ancestor, speech. ${ }^{1}$

We decided that a workshop on the subject of the nature and evolution of the relation as an early modern reporting mode would raise questions that have yet to be asked. We invited De Vivo himself to participate, and assembled discussants, many of whom have contributed papers to this collection. Debates both at the workshop and in the articles here grappled with several questions, easier posed than answered. First of all, what was the thing itself, that we chose to call the "relation"? Second, what was the trajectory of its history? That is, when and where did it appear, flourish, and fade, if fade it did? Third, what was the relation's genealogy, its Aristotelian first cause? Fourth, what was its proximate cause: what conditions enabled it to flourish? And, finally, what sapped its vigour and pushed it to the margins? The papers in this collection address these questions by looking at specific examples of the relation, and pondering its nature and the puzzles it presents.

\section{The thing itself}

The "relation" was a particular kind of report about notable things, usually unfamiliar or surprising. The term "relation" was only one of several names such reports might bear. We use it here for convenience, as modern scholarship has affixed no name to the phenomenon as a whole; rather, it has singled out 
parts that conventionally bear the name: the Venetian diplomatic relation, the travel relation, the Jesuit Relation. Let us try for a moment to delineate the phenomenon by surveying its boundaries. Clearly, not all early modern descriptions of the world were relations. For instance, Machiavelli's Prince or Hobbes's Leviathan were not relations, but treatises, expounding the realm of politics as the author sees it. Why, for all that they do relate things, are they not relations? In such works, the author is absent from the body of his text. The reader sees the product, and the process, of his ratiocination, but barely glimpses the thinker thinking; authorial conventions suppress him almost entirely. For contrast, consider another very famous work, Pascal's Pensées. There, the author is present, passionately, as an implicit example of the workings of heart and reason. But his meditative presence is not relational; it does not function as a literary bridge between the reader and the world, or, indeed, between the reader and the main subject (not Pascal's own soul and mind, but everyman's). Pascal never tells a reader something like, "Now when I contemplated Cleopatra's nose, I asked.... Nor, with their fragmentary nature, do the Pensées, as a relation would, lay out a coherent image of some fragment of the world. On the other hand, the essays of Montaigne, though not themselves relations in structure or design, brim with relational moments, worldly anecdotes where Montaigne himself, as if speaking straight to the reader, relates his own movements of mind, heart, and body. So, though not relations, Montaigne's Essais bear deep marks of a relational habit and technique that needs defining. Descartes, in the Discourses - a treatise to the bone, an abstract disquisition on how minds might do their job-does begin the work with a relational bridge, that famous reminiscence of his day spent thinking by a warm German oven. But once launched on their abstract consideration of method, his Discourses never return to that early anchor in an author, a place, and a time. These reflections on famous works suggest that the relation was at once a thing, a literary product, and a rhetorical and cognitive device that might surface, as with Montaigne and Descartes, in works that followed other rules and strategies.

A relation then, whatever was on its early modern title page, might be a discourse that explores, and expounds, some thing of note, where the author addresses his or her readership very directly, citing the authority of experience. Authors said, in effect, "Let me tell you about the distant land, the monstrous birth, the fierce battle, the secret practices of witches, for I have seen these things myself, or, at least, heard them from witnesses beyond reproach." The 
relation takes its force, and its authority, from the author's palpable presence as narrator, and from his or her engagement, and direct experience if possible, or often from careful communication with other witnesses who themselves deserve a reader's trust. Most relations we know today were written, but as we suggest below, the relational mode appeared as well in spoken language; for written relations, when closely examined, betray a broad oral streak.

\section{Trajectory and first causes: the history and genealogy of the relation}

The relation, as we know it, seems to have been a creature of print's first age. So far as we can tell, few such reports circulated in manuscript before Gutenberg. Nevertheless, as Filippo De Vivo and Andreas Motsch point out in their articles, its origins were far, far older. Moreover, despite the role of the press, the borders between print and manuscript circulation were uncertain, because, throughout print's first centuries, many relations passed from hand to hand, and from copyist to copyist. The relation was a loose genre, weakly codified then, which is one reason why it remains amorphous today.

At the same time, a plethora of kin and ancestors shaped the relation's habits. One key ancestor is the old custom of oral recounting of things true, or so seeming, and little known. Pilgrims and merchants back from travels, soldiers discharged from wars, villagers returning from business in town, hunters home from the chase surely regaled circles of hearers around many a table or fire. However, this vast, lost world of talk has left faint traces on medieval literature, rendering not whole tales, but merely the oral stratagems of other genres like the traveller's tale or the novella: "Now attend...let me tell you... now, I have seen with my own eyes..." and so on.

A second important ancestor was the practice, in law courts wherever Roman jurisprudence reigned, of giving coherent testimony under oath. As Andreas Motsch's essay observes, the original meaning of relatio was a deposition before a judge or, one might add, before any legal official, a notary for instance. "Ut refertur in actis: as is related in the notarial papers," notaries always wrote when cross-referencing (cross-relating). It is the same relation-verb, just a different form in a different Latin tense. The reports of Venetian ambassadorsthe famous relazioni-took their name, as De Vivo observes, from their official and formal nature as reports before the Senate. 
A third ancestral model was hagiography, which shared the relation's interest in remarkable things, and which always possessed its own conventions of witnessing. For authentication's sake, from the earliest days hagiographers had hastened to cite witnesses to saints' miracles, mortifications, moments of grace, and charitable deeds. In its opening words, even Luke's Gospel nods to living sources. The Lives of Saints would elaborate and sharpen his device. See, for a very early instance, the fifth-century Life of Saint Martin by Sulpicius Severus, where single miracles sometimes have their witnesses, or the scrupulously methodical, very direct address to readers by the Venerable Bede, at the outset of his eighth-century Life of Cuthbert:

\begin{abstract}
I have written nothing about the life of the saint without first subjecting the facts to the most thorough scrutiny and have passed on nothing to be transcribed for general reading that has not been obtained by rigorous examination of trustworthy witnesses. Indeed, before even beginning to write, I carried out a thorough investigation of the whole of the saint's glorious life, with the help of those who had actually known him. I occasionally mention some of their names in the body of the book so that you can see for yourselves exactly what the sources are. ${ }^{2}$
\end{abstract}

Just as in the early modern relation, Bede writes to build trust between author and reader. As "I", he is present in this passage; so too are "you" the readers. Bede is, if not a witness to the deeds of Cuthbert, most certainly a witness to his witnesses.

A fourth source is the writing of history. There, the medieval author himself sometimes does appear, to validate or enliven some part of a story. Gregory of Tours comes to mind, in later chapters of his Historia Francorum where he chronicles in passing his own dealings with Merovingian kings, but in Gregory the model is weak: the author surfaces sporadically; his presence is altogether peripheral to the message, structure, and truth-claims of his narrative. In many medieval histories, even when in the thick of politics, the author suppresses himself almost entirely, as does bishop Otto of Freising in his Deeds of Frederick Barbarossa, or Dino Compagni in his Chronicle of Florentine politics around the time of Dante's exile. On the other hand, many crusader tales, part chronicle, part pilgrim-narrative, do feature their author as combatant, participant, and witness: Villehardouin's record of the Fourth Crusade notes the 
author's participation in negotiations, and Joinville's Life of Saint Louis contains vivid sketches of the author's battles and his conversations with the king. Such chronicles have a clear kinship with early modern travel narratives, as do high medieval accounts of travels to the East, Marco Polo's for example, where the author figures as a frequent witness.

So the early modern relation did not spring from nowhere; it had many forebears. A full exploration of its braided genealogy, though, would be a very daunting task, demanding an infinity of close reading for hints of kinship and an arduous hunt for rare attributions or acknowledgments. In sum, we really do not know very well how, when, or where the relation, as rhetorical habit and epistemological method, actually took shape.

\section{Proximate causes and conditions that fostered the relation}

One source for the relation's emergence lay in the changing market for information. The early modern world did not invent information's value; news is always a thing of worth, and people will always trade in it. But for Europeans, prior to print's invention, news was more often a gift than a commodity. In an opaque and viscous world, with knowledge scarce, slow-moving, and often close-guarded (for trades, arts, and courtiers were wont to hedge their secrets), privy information about industry, commerce, politics, or human relations was a treasure, to mete out discreetly. To tell a special thing was to bestow a gift, one among the many custom demanded, given with all the usual expectation of reciprocity in one or another currency-loyalty, trust, aid, goods, services, restraint, or further information. The exchange of information, amid a dearth of data, was just one gambit in the game of canny entanglement that knit all society, all commerce, and all politics. De Vivo's article illustrates this state of affairs, showing how transcribed ambassadorial relazioni passed from hand to Venetian hand, sometimes given, sometimes lent, sometimes merely shown, as an item of exchange in a densely woven city.

The early modern age thus did not invent the exchange of news; medieval Europeans were never blind to the world, with eyes merely fixed on heaven. The seculum also mattered to them, and they had rudimentary networks along which news flowed more readily than elsewhere: merchants, the upper clergy, 
scholars, the servants of principalities come to mind. But in these networks the nerves were shorter and fewer, and the ganglia far less capacious than later.

Note too the impact of print's advent and its emergent market. ${ }^{3}$ Quite quickly, information, erstwhile gift, became more often a commodity. More plentiful, it moved farther, faster. The emergent information market sparked demand; if others knew, one too must know or be left behind in commerce, politics, or the struggle for the prestige that accrues to important knowledge. Accordingly, a need to know begat an appetite to know yet more. The knowledge market also fertilized production: if buyers were spending, whether in cash or other token, it paid to produce. Very gradually, an information commons emerged, old habits of secrecy yielding to open exchange, abetted by the circulation of books, pamphlets, newsletters, and hand-copies bearing news about the world. The 1603 Peruvian Jesuit relation in Franco Pierno's article offers a fine example of the widening of the market and the new speed of transmission. Released in Italian, the work soon reappeared in Latin, French, German, and Polish; within a few years readers across much of Europe held shared knowledge about Spanish missions in the Andes.

Meanwhile, with the Reformation's religious splits, the appetite for relations grew. Partisans of all confessions turned to the relation, a tool for assertion, aggrandizement, and self-defense. Religion's polemics invited reports of the virtues of one's own side, of unjust sufferings, miracles, victories, and other proofs of divine favour, and attestations to the folly, turpitude, misery, forlornness, and eventual doom of all rivals. As confessional struggle blanketed much of the continent, news of distant events became far more urgent than in the old days when the faith had been whole. Meanwhile, religious struggle spawned organizations devoted to the confessionalizing project, the Society of Jesus being only the most famous. Such bodies often used news of their own activities to rally the hesitant, convert scoffers, curry favour, and cow adversaries. Thus, the struggle for confessional supremacy mobilized and facilitated the flow of information; the need to convince the skeptical and to rally the hesitant put a premium on devices to validate the news. As Motsch and de Vivo both remark, the relation was a prestigious medium, resting as it did on the status and experience of its authors and on the good standing of its genre; it strove for self-validation, and, when it was polemical, thereby validated as well whatever cause it championed. 
Alongside and amid religious conflict, statecraft and politics were evolving. Early modern European states had longer arms, swifter nerves, and far more capacious and stable memories than their medieval counterparts. Their conflicts embroiled wider swaths of landscape. Two centuries of struggle for supremacy between France (Valois or Bourbon) and the Habsburgs of Vienna and Madrid tautened nerves across huge distances, as did pervasive war with the Ottoman Empire, a sprawling realm far vaster than any Christian kingdom. An example of this evolution is the difference between the geographic spheres of the Netherlands and England in 1450 and in 1650. In 1450 they were modest actors with North Sea and Baltic trading interests, plus ventures in the wine and salt trades of the Bay of Biscay, while in 1650 they spanned the watery globe, colliding with one another, and with France and Spain and Portugal, on almost any coast where a galleon could hoist sail. European politics and commerce spilled around the planet, so that distant news, whenever it touched statecraft or trade, paid readily. In their struggles, states mobilized and moulded information, one more tool of policy. ${ }^{4}$

Alongside these changes in religion, politics, and trade, there came a shift in the culture of cognition. The growing information market craved ever more novelty. New things did not sate but teased the appetite to trump old marvels with wonders even stranger: bizarre beasts more curious, native peoples yet more astonishing, treasures more dazzling. Empiricism at home, discovery abroad both stimulated a knowledge market that was readily fed and seldom sated by the flood of printed relations. Readers probably read not only to marvel, and revel in knowledge, but also to thrill with desire, or indignation, in titillating amalgam. Cannibals with gloriously naked wives in plenty, chieftains at once civil and cruel to the victims on whom they feasted: such spectacles appealed to a variety of appetites, seldom chastely contemplative.

This sketch, so far, helps to explain the presence and spread of the relation, but we also need to examine its nature. There are good reasons for the burgeoning consumption and production of news, in general, but what specifically in European culture brought forth relations, rather than treatises, disquisitions, or encyclopedia articles? The answer surely lies in Europe's lingering personalization of information exchange. The old gift-giving information economy did not fade swiftly. The older culture of secrecy meant that most information was still in some sense privy to the informant, and to its other guardians, to whom the informant, by virtue of position or shrewd inquiry, was often a privileged con- 
duit. And the old exchange culture meant that to impart news still established a tacit debt and personal tie, building a relationship that the teller hoped to trade on. So a tale without its teller was not easily imagined; or as Motsch notes, a relation, with its oral habits, always showed its narrator. The power, and prestige, and occasional wealth that attaches to privy information is indeed with us still, wherever opacity and influence conjoin. A major capital like Washington has things in common with an early modern court, with its information brokerstoday journalists, lobbyists, hosts, and canny gossips, who like the courtiers of earlier centuries trade in high-grade rumour. Modern transparency is only partial; what distinguishes the modern world from earlier times, however, is an information culture that works hard to uncover secrets and test rumours. We assume a right to clarity, and possess investigative machinery-journalism, internet gossip, legal process, and research—to achieve that light.

\section{The decline of the relation}

Our modern capacity for investigation, as fact, epistemic model, and ideal, probably provoked the relation's decline. As Europe moved into the Enlightenment, and beyond it, information grew ever more abundant, becoming cheaper, less precious and less charismatic, and acquiring as well new sources of authority. One may think of this process as Descartes' victory. Descartes by no means deserves all the credit for the cognitive shift, but the notion so prominent in Cartesian thought-that we should trust not the investigator, but his method-had countless repercussions. Descartes put it very clearly; he wanted to establish a method so powerful, and so clear and distinct, that just about anyone could follow it and clinch good results. The methods that triumphed over the next centuries were in fact not his, but methods indeed they were, and we can certainly trace a Cartesian shift in emphasis. What brought the relation down was the transfer of trust from the teller to the investigation itself, which, by the new standards, had to be conducted in ways open to the judgment of a wide jury of skilled commentators. In the pre-Cartesian world, there was small consensus about methods, except perhaps in the old university disciplines of theology, medicine, and law, with their scholastic logic and canon of wellparsed authorities. In a world with few clear methods of inquiry, and murky information, whom was a reader, or a hearer, to trust? Under such conditions, 
much as among Washington gossips or Wall Street observers today, reputation counted. Indeed, honour culture, which so prized the honest word, was swift to tie status to trustworthy speech. When it came to telling about a distant land, a wondrous beast, or a jarring move in politics, audiences must have been quick to ask "Who is telling us this?" So there was more to the relation than just a vestigial orality; hearers desired tellers, the better to trust the tale. The nemesis of the relation, as Motsch implies, was the Enlightenment's encyclopedia article, validated not by an author's voice, but by the great weight of expert inquiry on which it rested. The end of this evolution away from the relation is the modern scientific article, with its dry prose, passive verbs, and pervasive, abstract impersonality, doing its scrupulous, crushing best to render its authors utterly invisible. Meanwhile, as Motsch notes, some of the relation's narrative habits lived on, in altered form, in the new realistic novel. Many of these general observations receive ready confirmation in the essays that follow.

\section{Perspectives on the relation and its avatars}

Filippo de Vivo discusses the Venetian relazione, the genre that eventually lent its name, one among several rivals, to the early modern report on distant places. But, as de Vivo observes, the Venetian relazione was a very particular document, with its own institutional setting and legal rules. It was the eventual transcription of the oral relazione Venetian ambassadors delivered at a mission's end, a final official act, before the Senate. The custom and duty dated back to the middle thirteenth century, and the name attached this formal deposition to the solemnities of legal testimony. Historians, overly trustful, from von Ranke down to now, he asserts, have long used these papers without querying the forking pathways that finally brought them into archives and libraries. Venetian Relazioni served the state, informing it, and training its office-holders, but they also served their authors, and their readers as well, to whom they afforded both information and the prestige of special knowledge, for they were charismatic documents, resting as they did on the authority of their high-placed creators, and of the state that authorized, solemnized, and conserved them. Meanwhile, at times, an ambassador might exploit his relazione as an apologia for his own conduct, an argument for policy, or a device to advance his mission's entourage. Venetian relazioni were famous for their precision and for their 
reach; contemporaries, and later scholars, therefore both prized and mined them. But, if read carefully, they bear many traits of their oral origins. De Vivo finds ambassadors appealing to their own experience and urging their hearers to consult their own wisdom about the world. As charismatic documents, at once useful and rare, relazioni lent themselves readily to lending, giving, transcribing, printing, and sale. And like most early modern reports, they were seldom easily detached from their creators. Venetian relations, then, had all the traits of relations in general, and, almost certainly, they afforded a name to the literary form. As we shall see in other contributions, however, not all relations, or semi-relations, fit the Venetian model.

Franco Pierno's article takes its methods from literary analysis, reading closely for the poetics of a single text, the Breve relazione of Diego Torres Bollo (1603). Torres Bollo was at once author and compiler; he provided his relazione with a literary frame, a chastely clerical cousin of the framing device of Boccaccio and his imitators, to present five translated Spanish letters from Jesuits in Peru. But, Pierno explains, the framer also modified the letters themselves; the originals, all still extant, illustrate his subtle changes. Torres Bollo's Peruvian Relazione is different from the later Jesuit Relations from New France or elsewhere, showing little of their careful ethnography and empiricism. Rather, it transforms the native Peruvians into mythic types of angelic, childlike innocence, readily pried from devil worship. He recounts a legend, told years ago to the elders of a village, who told a Jesuit, who told the author of a letter of 1589, which Torres Bollo translates, that once there came a man with a black beard and twelve disciples, who planted a cross, only to be driven by heathen enemies to a spit of land that, miraculously, became an island. The mysterious blackbearded Santo escaped, floating on his coat across Lake Titicaca. Torres Bollo alludes to this long, long chain of witnessing, especially to its early links, and hints at the meaning of the story. Was the Saviour already treading the Americas, hallowing and readying the ground? Here is a narrative strategy that blends a traveller's inexpert empiricism with evocations of a religious realm at once familiar and enticingly alien. This double vision of Torres Bollo, of the other as at once charmingly different and yet, delightfully, in mysterious communion with his readers, will resurface in other ways in other relation literature, even in the more sober Jesuit ethnographies from New France. We shall see how other relations might also rely on witnesses to things the author himself could never observe. 
This is not the case with Carolyn Podruchny and Katie Labelle's account of some of the most famous of all relations, sent back to France by seventeenthcentury Jesuit missionaries to New France; in particular, those of the eventual martyr, the brilliant Jean de Brébeuf. These reports, in the usual way of relations, bring stark news of novel, distant places, via a witness, here the conspicuous missionary himself, whose gifted writing enlivens and sanctions his report's precise detail. En route to publication, Jesuit relations passed through assorted official hands, but, surely, nobody on the chain of compilers, censors, and editors thought to muffle Brébeuf's own voice. On the contrary, it paid the Order to keep missionary authors both visible and audible.

Alongside their accounts of the new lands beyond the edges of New France that the Jesuits were investigating, Brébeuf and his companions were themselves a chief subject of their relations. If it was the nature of relations to report things obscure yet notable or urgent, then, in Jesuit eyes, these tales of distant realms among the pagans had an obvious double burden: not only the strange land and its stranger inhabitants, but the courage, ingenuity, persistence, and deep faith of fellow Christians who staked wits, hearts and bodies to spread the faith. The more foreign, diffident, or hostile the natives, and the stranger the lands they inhabited, the more marvelous, more edifying, more appealing the tale of missionary struggles and, above all, the more glorious any eventual success or, if that was to be their end, martyrdom. Brébeuf, then, must be visible; he is a necessary hero.

In his own reports, Brébeuf's heroism is of another nature, of not heart but mind, for he was a brilliant student of the Wendat world, an acute observer and energetic linguist, whose growing mastery of their difficult tongue allowed him, ever so gradually, to enter the natives' confidence and use his growing comprehension of their world and values to win their tolerance and, with luck, he believed, their souls. His reports constitute an early modern ethnography now precious to historians of native America.

Yet knotty problems are raised by Brébeuf's long direct quotations of native speakers. As the authors show, these passages are an historian's treasure. To the extent that scholars can trust them, or at least decode them, they attend to the Wendat world, to political calculations, notions of community, and native images of the European intruders. They also offer some sense of the rhythm and cadences, large shape, and imagery of formal and informal native oratory. But clearly the Wendat speeches in Brébeuf's relations are by their 
nature a double confection, part native, part Jesuit, and the devilish problem is just which words are whose. We have no ready touchstone, no handy trove of seventeenth-century Wendat oratory or other discourse, so all decoding forces us to fall back on our sense of who Brébeuf was, and how he might design to render native speech. Formal speeches, like Aenon's to Brébeuf, conjured up the well-known set-piece orations in histories, from Herodotus through Caesar, and on down the centuries. When in a history European readers met speeches, they knew they read no faithful transcript of real words uttered, but rather a latter-day rendition of what a speaker really should have said. What then would Brébeuf have wished to capture in the oration of the Wendat leader? Aenon's speech had to demonstrate both his otherness and his sameness, wrapped into a single oratorical production. Brébeuf himself is of two minds about his hosts: he admires them, even while he repudiates their cosmology. And he attests to the complexity and cleverness of their oratory, but barely evokes it; rather, the translation itself illustrates less the speaker's cleverness than that of the missionary, who could catch the chief's oratorical drift, lodge it on paper, and relay it to European readers. The message here is less the canny speech than the clever hearing; the illusion of comprehension invites readers to share in the missionary endeavour.

Megan Armstrong reconnoitres the subtle boundaries of the relation by looking at a different literary form, the Holy Land pilgrim narrative, a venerable medieval genre that, she contends, in early modern times began to take on relation-coloration. In their bid for readership and in response to changing tastes for knowledge, Franciscan pilgrim authors came increasingly to frame the near-eternal tale of visits to the holy places in descriptions of their more mundane voyages across seas and lands less sacred. Armstrong anchors this curious blending of the worldly and the other-worldly deep in a Franciscan culture, dating back to the founder himself, of seeing the holy as suffusing all creation. At the same time, she holds, the continuing contrast between profane and sacred pervaded these Franciscan narratives; the details of the trip itself alert the mind but fail to address the heart as the narrator swiftly traverses seas and mountains, sometimes noting local conditions, but never delving. When he steps on sacred ground, however, his pace slows, and he moves to evocation of the stirring moments of sacred history. The tone also shifts, from mildly inquisitive to passionately engaged. So the histories, passing from the exotic to the familiar, and from relation-like travel tale to meditative writing akin to 
sermon, strive not to inform of novelties but to re-attach the reader's hearts to things already thoroughly known.

Like the relation, these Franciscan pilgrim narratives reveal the author and use him as a device to win a reader's trust; they claim authority by citing the writer's experience abroad, and, quite often, note his offices and schooling. In some histories, the writer is also a very visible witness. Most curious in this regard is the 1485 treatise by Suriano, who takes his readers to the holy places via an imagined dialogue with his sister, a Poor Clare nun, whom he leads, in text only, to the holy sites, and, through her, expounds their meaning to his readers. The distant events of the life of Christ pass, then, through a constructed Franciscan witness, and a constructed fictitious speech, into the largely passive ears of a semi-fictitious absent hearer, with whom the reader is also listening. As empiricism gained ground, the manifest artificiality of such devices would banish them. Armstrong shows the growing influence of the relation mode, for Franciscan Holy Land narratives are a case of adaptation, of evolution. They illustrate how the relation was not only a genre, albeit an informal one; it was also a mode of writing that other genres, even well-defined ones like the pilgrim tale, might adopt and adapt to their own ends.

Maria João Dodman presents an early sixteenth-century narration of Brazilian exploration, the Diário da Navegação of Pero Lopes de Sousa. The author was a brother of the commander of an important royal fleet that in 1532, some decades after the original European discovery, returned to South America to reassert royal claims and foster trade and settlement. Like the Franciscan writings, this work is a hybrid, only partly a relation. But the mix is different: de Sousa, like the friars (and unlike the Venetian ambassadors), chronicles his own movements, step by step and day by day, but takes no time out for pious contemplation. Rather, in the mode of travel tales, he presents things as they arise, interweaving reports of struggles with rough seas and rougher natives with encomia praising the rich lands his co-nationals hope to retain. His ethnography is shallow, and his capacity for landscape writing only mediocre, but his eye for wind and weather is well-schooled and keen. Meanwhile, the author is his own hero, never quailing, firing the cannons, always on deck, rounding the stormy cape and saving the day for his ship, men, and king. In organization and spirit, the Diário had much in common with a plain old logbook, and, indeed, de Sousa almost certainly had a formal log at hand when fleshing out his text with cannibal anecdotes and musings on nature's local bounty. As Dodman 
remarks, it is hard to tell whether he was still sea-tossed when writing, or snug in Lisbon; the text has riddles. Unlike a simple log, the Diário has vision and, Dodman argues, point of view and programme: down with France and other interlopers, and up with Portugal, the better governor and occasional handy civilizer of the grateful indigenes! A mongrel work of several genres, the battletale among them, the Diário partakes of the relation via links to the growing corpus of travel narratives in the hands of early sixteenth-century Portuguese readers. As Dodman notes, Portuguese travel writing was an eclectic model, and it had an avid public. One can add to that the vivid nature of the experience itself, and the author's ambition to rise in royal service, both of which could push him from dry record to lively story.

Margaret Reeves considers an early text by Margaret Cavendish, wife to a great royalist and commander, a writer, an enthusiast for natural science, and an exile on the continent from the English Civil Wars. Still only 33, Cavendish published "A True Relation of my Birth, Breeding and Life," in which she asserted her parental family's restraint and rectitude, deplored the depredations of her Parliamentarian adversaries, and battled the detractions couched in assorted rumours about her actions in the family's interest, especially her occasional petitioning in London. Cavendish claims to be writing for posterity, not for her contemporaries, and inserts plain commonplaces about London and Antwerp to hint to readers that she intends a future audience ignorant of such things. Reeves ponders Cavendish's title: redundancy notwithstanding, "True Relation" appeared often as a title, as if plain "Relation" could not convince. Many "true relations" concerned politics, and they were plentiful in the England of the 1640s, where insurrection, civil war, and constitutional turmoil were constant. Cavendish's own choice of title, Reeves argues, shows that, in her mind, her own work was political and polemical. It addressed the politics of the entire realm, and the position of her own prominent family by marriage and, at the same time, it also engaged the personal politics of reputation, which floated malicious rumours about the author's own writing, petitioning, dressing, social behaviour, and character.

Cavendish's choice of title thus seems to have had several meanings. On the surface, in the relation mode, it asserts a straightforward claim to accuracy. And, as with most relations, it binds the author to her subject. But that second move is redundant: anyone, supposedly, could write a self-relation and that is why, normally, nobody claimed to do so. One related distant things, strange 
things, marvelous things, shocking things, not humdrum details from heart and home. There is an interesting displacement of genre here, altogether deliberate. The irony of the title only succeeds if the foil, the normal relation, is available to readers' minds. So the Cavendish project illustrates both the edges of the genre of the relation and, by negation, its implicit centre.

Andreas Motsch takes a very long view of one particular variety, the relation as a distinct form of travel writing. At the same time, he couches its evolution in a sweeping view of relations in general. Motsch sees the travel relation as having a poetics and a hermeneutics, which evolved with changes in European culture. To his eye, travel literature struggled for acceptance; there was a wide-spread belief that travellers exaggerated and lied. Accordingly, their writings needed devices to give authority, and the relation, with its links to legal speech and official reporting, was one way to garner credibility. And relations, as a genre, often attached to institutions with power: states, and, famously, potent religious orders like the Jesuits. They were prestigious documents, at once self-validating and conferring legitimacy. Motsch sketches out the long history, from the origins of the relation in legal deposition, across the genre's early modern bloom, into its slow withering in the Enlightenment. But for Motsch, the relation did not die out so much as evolve into a multitude of latter-day forms, such as the colonial survey, the naturalist's field papers, or the ethnographic report. Motsch stresses the double duty of travel literature, as narrative and as description. With the decline of relating itself, in empirical reports narrative wanes, leaving in its place bare social or natural science. Meanwhile, in the humanities, the narrative, the tale of travel, would live on in later travel narratives that centre on the travellers themselves. The old relation had aimed both to entertain and to instruct, but its literary heirs often gave up on the fusion, taking sides as empiricism shrugged off compassion, wit, and literary flourishes.

Motsch contends that early modern travel literature was no casual product of changes in European culture. Rather, he argues, it itself helped shape the evolution of intellectual culture, feeding empirical inquiries and also shaping the transformation of the novel, nudging fiction away from Renaissance fantasy towards nineteenth-century fact. The plain writing style, stripped of baroque flourishes, that fed relations' credibility, readily spilled over into fact-laden novels. 


\section{Editorial envoi}

The synoptic essay by Andreas Motsch helps us, the editors, to bring our own relation of this intellectual project to its close. In the April workshop, Motsch was already urging all participants to the long view and to a bracingly synoptic vision of the relation's many varieties and complex connections to the culture and politics of its production and reception. His admonitions lodged in our minds and helped us in our ensuing dialogue with all the authors of the essays collected here. We have found this whole inquiry a fascinating project. To our eyes, these essays suggest some of this history's many shades and complexities. The relation, which was indeed at the very least a tacit genre, turns out to have been both a literary mode and a communicative performance, implicitly moving us to think more attentively about just how the texts we study functioned and evolved. Subtle close reading and careful situating in both institutional practices and literary modes are the methods that promise the richest rewards. There is a good deal more to be learned about the deep shifts in Europe's habits of bringing home word of things not easily believed.

\section{Notes}

1. Thomas Cohen, London Review of Books (28 February 2008), pp. 1-4.

2. The Age of Bede, trans. J. F. Webb, ed. D. H. Farmer (Penguin: Harmondsworth, 1965), p. 41. For Sulpicius Severus, The Life of Saint Martin, any edition, see chapters 5, 24, and especially 25 , a long interview with the saint.

3. Andrew Pettegree, The Book in the Renaissance (New Haven: Yale University Press, 2010).

4. Peter Burke, The Fabrication of Louis XIV (New Haven: Yale University Press, 1992); Jacob Soll, The Information Master: Jean-Baptiste Colbert's Secret State Intelligence System (Ann Arbor: The University of Michigan Press, 2009). 